\title{
FEED BUDGETING : AN AID TO PROFITABLE MANAGEMENT :
}

\author{
M. A. Monteath \\ Field Manager, Otago/Southland, Gemco, Dunedin
}

\section{Abstract}

The challenge to management in producing milk, meat and wool profitably from pasture is briefly described and the role of various management manipulations of feed and stock in meeting this challenge is discussed. Feed budgeting is helpful in the making of decisions about some of these manipulations. The construction of a management feed budget is described, two examples are given of its use, and the implications of possible inaccuracies in the data used in feed budgeting are discussed.

\section{THE CHALLENGE TO MANAGEMENT}

Iт Is ASSUMED here that the farm manager is faced with the challenge of maximizing profit from one or more stock enterprises. Like any production manager in a manufacturing business, the farm manager converts a raw material into a salable product and in doling so strives to make a profit. In the farming context the profit is achieved by selling milk *and/or meat and/ or wool produced by processing a raw material — feed with processing machines - animals.

This presents farm management with the challenge of achieving the most profitable combination of feed supply with feed consumption by animals throughout the production period. Usually the production period is approximately one year, and $90 \%$ or more of the feed is obtained from pasture. The processing units are either adult stock plus offspring for limited periods (e.g., breeding ewes and cows), or continuously productive individuals (e.g., dairy cows, cattle being grown for replacements or slaughter, sheep replacements), or various combinations of these two kinds of stock.

\section{THE ROLE OF MANAGEMENT DECISIONS}

In ewe, and beef and dairy' cow enterprises, stocking rate, lambing or calving date, and breed of sire and dam are the three 
important management decisions which are made at the start of each new production period. For high profitability, the aim must be a stocking rate which gives sufficient stock numbers to utilize profitably all the feed grown in an average year. Also the lambing or calving date must ensure that the adult's milk production does not suffer a feed-induced reduction. Past performance, local experience, and educated guesstimates (based on nutrition standards and estimated monthly feed supply) should be sufficient to make these decisions.

All other management decisions concerning feed supply, feed usage and manipulation of the processing machines are made as the production year unfolds, and deal with reality. These management decisions are used to create an actual feed demand and modify the actual feed supply so that the two coincide in the most profitable way. The annual profitability of the stock production system(s) depends on, and is affected by, the profitability of each of these individual management decisions.

It is in the making of these individual management decisions that feed budgeting can be a management aid. By completing a feed budget, a better decision should be made than would otherwise have been the case. If improved decisions are made each time over the course of the production period, then the end result will be improved profitability from the stock enterprises.

\section{WHAT IS A FEED BUDGET?}

What then is a feed budget in this context? It is a statement of available feed and likely stock feed requirements in an immediate short-term future period. The actual period involved will vary according to the management problem requiring a decision. The feed "income" side of the budget is comprised of current reserves plus expected growth. The feed "expenditure" side is derived 'from the numbers and kinds of stock on hand, their feed intakes associated with the performance expected from them over the budget period, and the pasture reserves remaining at the end of the budgeting period.

The unit of feed used in the budget must take into account differences in feed quality. Digestible dry matter (DDM) probably is the most suitable practical unit. However, there are farm situations where there is no knowledge cf pasture growth rates and digestibility of herbage - e.g., tussock country. In such cases where "feed budgeting can only be done by using "ewe" or "cow grazing day" units the budget will be less accurate. If 
grazing days are used, it is important to note the stock performance which is associated with the achievement of the expected number of grazing days. Comparison of the income and expenditure sides of the feed budget will show a feed surplus or deficit.

All the possible uses of surplus feed should be noted and the return per kilogram of digestible dry matter calculated for each of them. Likewise with a feed deficit. All the possible means of eliminating the deficit should be noted and the cost per kilogram of digestible dry matter calculated for each of them. Having ranked the alternatives on a profit or cost basis, consideration can then be given to any other important non-profit constraints and a decision made which best incorporates all factors.

Two examples of feed budgets are given in Tables 1 and 2 .

The details of the decisions to be made will vary between enterprises and farms but will relate to the kinds, numbers and

\section{TABLE 1}

50 ha pasture, 1000 ewes of $55 \mathrm{~kg}, 80025 \mathrm{~kg}$ lambs growing at $1.5 \mathrm{~kg} /$ week mid-January. Pasture reserves seem to be increasing - will this continue? If so what should be done about it?



Surplus of $6500 \mathrm{~kg}$ DDM by February 13

\section{Alternative uses of surplus}

(1) Buy and fatten $25 \mathrm{~kg}$ store lambs at $1.5 \mathrm{~kg} / \mathrm{wk}$

(2) Increase liveweight of ewes by $2.6 \mathrm{~kg}$

(3) Sell hay

\section{Decision}

On returns alone buy in 400 store lambs

But (1) difficult to get store lambs, therefore estimated net profit may be only $80 \mathrm{c} /$ hd because of high purchase price,

(2) killing space can be difficult to get when needed in mid-February. Therefore management decision is put weight on ewes unless can get lambs at below February schedule rates.
$7.5 c$ (at net profit of $\$ 1.20 /$ hd)

5.0c (if still have extra liveweight at mating)

$1.5 \mathrm{c}$ 
timing of stock sales or purchases, the priorities and levels of feeding of different classes of stock and the performance expected of them, and the 'amounts, forms and timing of feed conserved, sold or purchased. The value of the feed budget is that it replaces subjectivity with objectivity and encourages a rational and logical approach to the making of these management decisions.

\section{TABLE 2}

50 ha pasture, 15020 -month-old steers at $370 \mathrm{~kg}$ growing at $0.7 \mathrm{~kg} / \mathrm{day}$ mid-March. In mid-April 250 6-month-old steers of $200 \mathrm{~kg}$ coming in. Winter feeding of forage crop starts on June 1.

Pasture rates of growth are declining — should cattle bc sold, or arrival of calves delayed, or feed bought in?

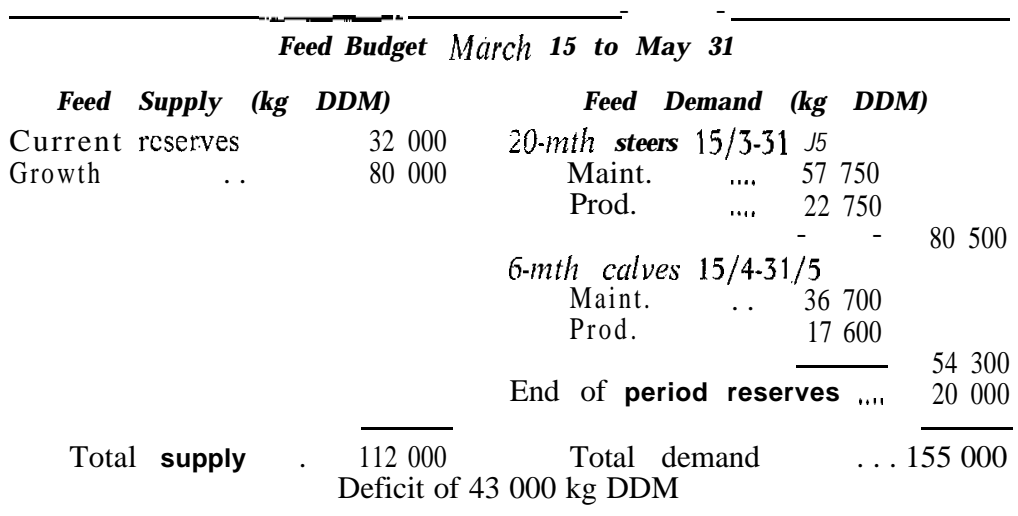

Alternative means of eliminating the deficit

Cost per $\mathrm{kg} D D M$ eliminated

(1) Sell 20-mth cattle .... ...... 3.5c

(2) Postpone purchase of 6-month calves'." $\ldots . \ldots . . .5 .0 \mathrm{c}$

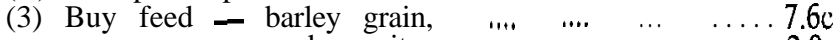
or bag nitrogen $\ldots \quad \ldots \quad \ldots \quad 2.0 \mathrm{c}$

\section{Constraints}

(1) Will take 7 days to organize sale of 20-month cattle

(2) Application of $\mathrm{N}$ - only 40ha suitable, costing bascd on $\mathrm{N}$ applied immediately at rate of $50 \mathrm{~kg} \mathrm{~N} / \mathrm{ha}$ as urea.

\section{Management Decision}

(1) Apply $50 \mathrm{~kg} \mathrm{~N} / \mathrm{ha}$ (as urea) to 40 ha immediately (eliminates 20000 $\mathrm{kg}$ DDM).

(2) Sell 47 20-month-old beasts immediately (eliminates '23 $000 \mathrm{~kg}$ DDM)

(3) Review feed reserves and re-budget feed no later than mid-April. 


\section{HOW TO CONSTRUCT A FEED BUDGET}

In order to construct a feed budget, current feed reserves, likely rates of pasture growth, stock feed requirements, and end of period reserves must be known. In the farm situation, current feed reserves of hay, silage, forage crop, grain and crop residues can be easily and accurately assessed. Current feed reserves in the farm of standing pasture cannot be so accurately assessed as practical considerations permit only an eye 'assessment method. This is usually based predominantly on height with some allowance being made for species, sward density and stage of maturity. Without actual measurement checks, this kind of eye assessment will produce errors in the estimate of actual feed reserves on pastures. However, this need not be a serious limitation to feed budgeting. The pasture feed reserve is a pool of feed to which feed is being added by growth and removed- by gnazing. Management is trying to achieve the most profitable coincidence of actual feed supply and actual use, and the degree of coincidence will be indicated by the change in estimated size of the pasture pool. Provided the manager 'has a consistent standard between paddocks and successive feed budgets, he will be accurate in discerning changes in the pasture reserve pool. It seems in practice that it is reasonably easy to achieve the consistency and accuracy necessary to discern accurately changes in the size of the pasture reserves.

An accurate prediction of future pasture production is desirable. However, the opportunities for obtaining a reliable and accurate prediction vary greatly according to locality, pasture type and kind of grazing of any particular farm. There are very few locations in New Zealand where pasture rates of growth have bsen recorded for more than 5 years and subsequently published. For those that are available and used, it is important to compare their cutting interval with the interval between grazings on the farm that is being feed budgeted. Also local soil fertility, soil moisture and climatic differences must be recognized and allowed for. Nevertheless, these limitations and the inherent errors of prediction can be tolerated, albeit somewhat reluctantly, because the pasture feed reserve pool acts as a buffer between actual feed usage and pasture growth.

Likewise, although animal nutritionists still have some reservations about the accuracy of the estimates of feed requirements for grazing animals, the buffer of pasture reserves allows any feed requirement inaccuracies to be tolerated. Provided changes in pasture reserves are regularly and accurately assessed, 
the effect of inaccuracies in growth and feed requirement predictions can be minimized.

At the same time, the effectiveness of management should also be checked by monitoring stock performance. Milk can be measured from dairy cows daily if necessary as well as liveweight change. Wool weights, lambing percentage and carcass weights, while useful guides to overail annual stocking rate with sheep, are too historical to be of any use as a management check. Ewe and lamb liveweight change is a much more useful yardstick and strategic weighing of sheep is an essential ingredient and adjunct of feed budgeting for management decision marking. Likewise, strategic weighing of beef cattle is essential in feed budgeting beef enterprises.

\section{THE VALUE OF FEED BUDGETING}

In view of the possible inaccuracies and the need for weighing stock, is feed budgeting worth the effort? In the writer's opinion, yes, but only where managers are striving to extract more profit from their stock enterprises.

First, it is important to remember that management decisions concerning supply of feed, use of feed, and manipulations of stock have to be and will be made irrespective of whether perfect knowledge, or no knowledge exists - no conscious decision is still a decision. Management has been defined as "the art of decision-making in a state of imperfect knowledge". To condemn or reject feed budgeting as a management aid because of the imperfections of the information it uses will tend to keep dairy and meat and wcol production management as an art rather than encouraging its development as a sophisticated skill.

Second, feed budgeting is of value in that it encourages rational and logical consideration of, and assigns priorities to, the many factors of animal pasture husbandry which must be integrated to best advantage.

Third, feed budgeting is an effective way of forcing farm managers to regularly and thoroughly consider and assess feed supply and feed demand and the current and future balance between them.

Fourth, it encourages a better understanding of the milk, meat and wool production processes. The relevance and impact of new knowledge can be quickly assessed in practical terms and therefore better definition of research avenues and their priorities is encouraged. 
In closing this series of three papers on feed budgeting, it is important to remember that the concept is not new. Feed budgeting in some form or other has been practised to a greater or lesser extent by all New Zealand farmers and farmers before them right back to nomadic herdsmen days probably. What is new is the improved knowledge of the mechanics of milk, meat, and wool production and an awareness of how a detailed and formalized feed budget may assist management to best exploit this knowledge. It has recently become more formalized and detailed because of efforts to squeeze even greater production and profit out of New Zealand's ability to grow feed from traditional grass/clover swards. 